\title{
Identification of Unique Nuclear Regulatory Proteins for the Insulin Receptor Gene, Which Appear during Myocyte and Adipocyte Differentiation
}

\author{
Antonio Brunetti, ** Daniela Foti, ${ }^{*}$ and Ira D. Goldfine* \\ * Division of Diabetes and Endocrine Research, Mount Zion Medical Center of the University of California, San Francisco, San \\ Francisco, California 94120; Departments of Medicine and Physiology, University of California, San Francisco, San Francisco, \\ California 94143; and ${ }^{\ddagger}$ Cattedra di Endocrinologia dell'Università di Catania, Ospedale Garibaldi, 95123 Catania, Italy
}

\begin{abstract}
To define the molecular mechanism(s) that activate insulin receptor gene transcription during cell differentiation, we tested nuclear extracts from BC3H-1 muscle cells for their binding to the 5'-flanking region of the human insulin receptor gene. DNA binding activity of nuclear extracts was low in undifferentiated BC3H-1 cells and increased significantly during differentiation. Gel retardation assays, combined with DNase I footprinting, showed that the increased insulin receptor gene transcription occurring during differentiation was directly correlated with the appearance of DNA binding proteins that specifically interacted with two AT-rich sequences of the regulatory region of the insulin receptor gene. Fibroblast growth factor, a known inhibitor of the transcription of muscle-specific DNA binding proteins, did not inhibit the appearance of these insulin receptor DNA binding proteins. When 3T3-L1 cells differentiate from preadipocytes to adipocytes, insulin receptor gene transcription significantly increases. In differentiated adipocytes, the same two insulin receptor DNA binding proteins markedly increased. Reporter gene analysis with the two AT-rich sequences demonstrated that both of these regions of the insulin receptor gene had the characteristics of promoter rather than enhancer elements. Thus, these proteins interacting with these AT-rich sequences may have major importance in regulating the expression of the insulin receptor in target tissues. ( J. Clin. Invest. 1993. 92:1288-1295.) Key words: transcription • differentiation - gene expression - transacting factors - fibroblast growth factor.
\end{abstract}

\section{Introduction}

In muscle, insulin regulates a number of key metabolic functions, including membrane transport, enzyme activity, and protein turnover (1). The initial interaction of insulin with muscle and other cells is via its receptor located in the plasma membrane (2-5). Cultured mouse and rat cell lines have been employed to study the in vitro regulation of the muscle insulin receptor $(6,7)$. These cells grow as undifferentiated myoblasts when kept at low densities in media with high serum concen-

\footnotetext{
Address correspondence to Antonio Brunetti, M.D., Ph.D., Division of Diabetes and Endocrine Research, Mount Zion Medical Center of the University of California, San Francisco, P.O. Box 7921, San Francisco, CA 94120.

Received for publication 25 April 1991 and in revised form 20 April 1993.
}

J. Clin. Invest.

(c) The American Society for Clinical Investigation, Inc. 0021-9738/93/09/1288/08 \$2.00

Volume 92, September 1993, 1288-1295 trations (8-10). However, when confluent cells are grown in media with low serum concentrations, the cells morphologically differentiate into myocytes (8-11). Concomitant with differentiation into myocytes, there is an increase in insulin binding to its receptor $(6,12,13)$.

BC $3 \mathrm{H}-1$ cultured mouse muscle cells have been studied extensively and show a 5- to 10 -fold increase in insulin receptor content when myoblasts differentiate into nonfusing myocytes $(6,12,13)$. In comparison with undifferentiated myoblasts, myocytes demonstrate enhanced effects of insulin on the regulation of several biological functions, including glucose and amino acid transport, protein kinase activity, and phospholipid turnover $(6,14,15)$. In target cells the insulin receptor has been shown to be under the regulation of hormones, metabolites, and differentiation $(2-5,16,17)$. Recently we investigated the effect of muscle differentiation on the insulin receptor in $\mathrm{BC} 3 \mathrm{H}-1$ cells (12). Increased insulin receptor content occurred after differentiation and reflected an increase in insulin receptor biosynthesis. This was accompanied by a 5- to 10-fold increase in insulin receptor mRNA abundance.

Myogenic differentiation involves the determination of multipotent stem cells to monopotent myoblasts followed by differentiation into myocytes that express muscle-specific genes. Recently, several proteins, homologous to the members of the myc family, have been reported to play a major role in skeletal muscle cell differentiation. These proteins include MyoD1 and myogenin $(18,19)$. When $\mathrm{BC} 3 \mathrm{H}-1$ myoblasts transform into myocytes, there is a marked increase in the gene expression of muscle specific proteins such as creatine phosphokinase and the nicotinic acetylcholine receptor $(8-11,13,20)$. When the gene expression of the nuclear regulatory protein myogenin in $\mathrm{BC} 3 \mathrm{H}-1$ cells is blocked by either treatment with fibroblast growth factor (FGF) ${ }^{1}$ or by treatment with an antisense oligomer to myogenin, muscle differentiation and the expression of muscle specific proteins is prevented (20). However, neither FGF nor antisense myogenin oligonucleotide prevent the expression of the insulin receptor that occurs during differentiation $(13,20)$. Thus, the insulin receptor in muscle is under the regulation of other regulatory proteins.

The insulin receptor promoter has been sequenced and analyzed (21-25). The promoter region extends from the ATG codon $(+1)$ to $\sim 1800$ bp upstream where an $A l u$ sequence begins. The insulin receptor promoter has neither a TATA box nor a CAAT box, but has common sequences for $\mathrm{Sp} 1$ and other nuclear binding proteins (21-26). In this study we have analyzed the regulatory region of the insulin receptor gene using a gel retardation assay combined with DNase I footprinting

1. Abbreviations used in this paper: CAT, chloramphenicol acetyltransferase; FGF, fibroblast growth factor; GAPDH, glyceraldehyde-3-phosphate dehydrogenase; LSC, liquid scintillation counting. 
(27). We find that there are at least two insulin receptor DNA binding proteins in $\mathrm{BC} 3 \mathrm{H}-1$ cells whose expression increases markedly during differentiation. These proteins are also observed in 3T3-L1 cultured adipocytes and other cells that readily express insulin receptors.

\section{Methods}

Materials. The following were purchased: Hepes, PMSF, bacitracin, antipain, and leupeptin from Sigma Chemical Co. (St. Louis, MO); $\left[\alpha^{32} \mathrm{P}\right] \mathrm{CTP}(800 \mathrm{Ci} / \mathrm{mmol}),\left[\alpha_{-}{ }^{32} \mathrm{P}\right] \mathrm{ATP}(800 \mathrm{Ci} / \mathrm{mmol}),\left[\alpha-{ }^{32} \mathrm{P}\right]-$ UTP $(3,000 \mathrm{Ci} / \mathrm{mmol})$, and $\left[{ }^{14} \mathrm{C}\right]$ chloramphenicol $(53.1 \mathrm{mCi} /$ mmol) were from DuPont-New England Nuclear (Boston, MA); protein assay reagent and dithiothreitol (DTT) from Bio-Rad Laboratories (Richmond, CA); DNase I from Worthington Biochem. Co. (Freehold, NJ); poly(dl-dC) and poly(dA-dT) from Pharmacia Fine Chemicals, Inc., Piscataway, NJ; pCAT-Basic vector, pCAT-Promoter vector, pSV- $\beta$-galactosidase control plasmid, Escherichia coli strain HB101, $n$-butyryl coenzyme A from Promega Biotec (Madison, WI); restriction enzymes were obtained from Bethesda Research Laboratories (BRL), (Gaithersburg, MD); 22-mer double stranded synthetic oligonucleotides representing consensus binding sites for Spl, Apl, Ap2, Ap3, and NF1 /CTF from Stratagene (La Jolla, CA); DME H-21 with minimal Eagle's medium amino acid supplement, penicillin, streptomycin, FBS, PBS, and trypsin from the Cell Culture Facility, University of California, San Francisco, CA. The following were gifts: basic fibroblast growth factor (FGF) from Dr. T. Scheuermann, California Biotechnology, Inc. (Mountain View, CA); plasmids containing cDNA for insulin receptor (28) and glyceraldehyde-3-phosphate dehydrogenase (GAPDH) (29) from Dr. G. I. Bell (University of Chicago), and Dr. B. Rapoport (University of California, San Francisco), respectively.

Cell culture conditions. BC $3 \mathrm{H}-1$ mouse muscle cells were cultured as described previously $(12,13)$. Undifferentiated cultures were maintained at subconfluent densities in DME medium $\mathrm{H}-21$ with $20 \%$ FBS. Differentiation of $\mathrm{BC} 3 \mathrm{H}-1$ cells was induced by exposing myoblasts to media containing $1 \%$ FBS. For experiments with undifferentiated BC3H-1 myoblasts, cells were used after $3 \mathrm{~d}$ in culture with continuous $20 \%$ FBS. Where appropriate, FGF was added to cultures at a concentration of $30 \mathrm{ng} / \mathrm{ml}$. HepG2, IM-9, and HTC cells were also grown in the same medium as $\mathrm{BC} 3 \mathrm{H}-1$ cells with $10 \%$ FBS.

Nuclear run-on transcription assay. Previously published procedures were used to study the transcriptional activity of the insulin receptor gene during differentiation of $\mathrm{BC} 3 \mathrm{H}-1$ cells $(13,20)$. Briefly, nuclei were isolated from $\mathrm{BC} 3 \mathrm{H}-1$ myoblasts and myocytes either in the presence or absence of $30 \mathrm{ng} / \mathrm{ml}$ FGF and allowed to continue transcribing in vitro in the presence of $\left[{ }^{32} \mathrm{P}\right] U T P$. The radioactivity incorporated into RNA in the transcription reactions was hybridized to filters containing the complete protein coding sequence of either insulin receptor (28) or GAPDH (29), and measured by autoradiograms.

Protein extracts. Nuclear extracts were prepared from $\mathrm{BC} 3 \mathrm{H}-1$, HepG2, IM-9, and HTC cells by the method of Dignam et al. (30). Briefly, $1.0 \times 10^{8}$ cells were washed with $\mathrm{PBS}$ at $4^{\circ} \mathrm{C}$ and harvested into buffer A ( $10 \mathrm{mM}$ Hepes pH 7.9, $1.5 \mathrm{mM} \mathrm{MgCl}_{2}, 10 \mathrm{mM} \mathrm{KCl}, 0.5 \mathrm{mM}$ DTT). After centrifugation ( $1,200 \mathrm{rpm}$ for $10 \mathrm{~min})$, cells were resuspended in buffer $A$ and kept on ice for $10 \mathrm{~min}$. Cells were then homogenized with a glass Dounce (type B) and centrifuged at 3,000 rpm. Equal number of nuclei from myoblasts and myocytes were resuspended in buffer B ( $20 \mathrm{mM}$ Hepes, pH 7.9, $0.55 \mathrm{M} \mathrm{NaCl}, 1.5 \mathrm{mM} \mathrm{MgCl}{ }_{2}, 0.2$ mM EDTA, 25\% glycerol, $0.5 \mathrm{mM}$ DTT, $0.5 \mathrm{mM}$ PMSF, $2 \mu \mathrm{g} / \mathrm{ml}$ antipain, $1 \mu \mathrm{g} / \mathrm{ml}$ leupeptin), and homogenized. The suspension was centrifuged for $1 \mathrm{~h}$ at $35,000 \mathrm{rpm}$ and the supernatant dialyzed against buffer C ( $15 \mathrm{mM}$ Hepes pH 7.9, 20\% glycerol, $1 \mathrm{mM}$ EDTA, $40 \mathrm{mM}$ $\mathrm{KCl}, 0.5 \mathrm{mM}$ DTT, $0.5 \mathrm{mM}$ PMSF). Final protein concentrations in the extracts were determined using the colorimetric assay of Bradford (31). The extraction of nuclear protein $(1-2 \mathrm{mg} / \mathrm{ml})$ was the same for myoblasts and myocytes. Nuclear extracts of 3T3-L1 preadipocytes and adipocytes (32), normalized by measuring the concentration of the serum response element binding protein, were kindly provided by Dr. M. Alexander (Harvard University).

Gel retardation assay. Binding reactions were performed with $4 \mu \mathrm{g}$ of nuclear extract in the presence of increasing concentrations of poly $(\mathrm{dl}-\mathrm{dC})$ as competitor DNA in a buffer containing $15 \mathrm{mM}$ Hepes (pH 7.9), $1 \mathrm{mM}$ EDTA, $40 \mathrm{mM} \mathrm{KCl}, 0.5 \mathrm{mM}$ DTT, and $5 \%$ glycerol (33). After $15 \mathrm{~min}$ of incubation at room temperature, $1-3 \mathrm{ng}{ }^{32} \mathrm{P}-5^{\prime}-$ end-labeled probe DNA was added, the reaction mixture was incubated for an additional $30 \mathrm{~min}$, and the reaction products were then separated by electrophoresis through a nondenaturing $6 \%$ polyacrylamide gel in $0.5 \times \mathrm{TBE}(1 \times \mathrm{TBE}=50 \mathrm{mM}$ Tris, $50 \mathrm{mM}$ boric acid, and $1 \mathrm{mM}$ EDTA). Gels were then dried and subjected to autoradiography overnight at room temperature. In the absence of poly (dl-dC), the end-labeled probe DNA remained at the top of the gel due to its interaction with nonspecific DNA-binding proteins in the nuclear extracts.

To obtain probe DNA for gel retardation assays, a clone containing $1.8 \mathrm{~kb}$ of 5 ' genomic sequence for the insulin receptor (34) was digested into five fragments with appropriate restriction endonucleases and end-labeled them with $\left[{ }^{32} \mathrm{P}\right] \mathrm{dATP}$ and $\left[{ }^{32} \mathrm{P}\right] \mathrm{dCTP}$ using DNA polymerase I (35).

Footprinting assay. For the DNase I footprinting assay, $10 \mathrm{ng}$ of each fragment was labeled with ${ }^{32} \mathrm{P}$ at the upstream $5^{\prime}$ end and reacted with $8 \mu \mathrm{g}$ of nuclear protein. Poly ( dl-dC) was used to compete for nonspecific binding. The reaction mix in a $25-\mu$ l volume was digested with $2.5 \mu \mathrm{l}$ of DNase $\mathrm{I}(10 \mu \mathrm{g} / \mathrm{ml})$ at $22^{\circ} \mathrm{C}$ for $1 \mathrm{~min}$ in the presence of 5 $\mathrm{mM} \mathrm{MgCl}{ }_{2}$ and $2.5 \mathrm{mM} \mathrm{CaCl}_{2}$. Digestions were terminated by adding EDTA to a final concentration of $12 \mathrm{mM}$ and placing the samples at $4{ }^{\circ} \mathrm{C}$. Products were then separated on a $6 \%$ polyacrylamide gel as described above, and the wet gel was exposed to $\mathrm{x}$-ray film for $2 \mathrm{~h}$ at $4^{\circ} \mathrm{C}$. The major shifted band and the band representing unbound probe were located by autoradiography, excised from the gel, the labeled DNA was extracted as described by Maxam and Gilbert (36), and separated on a $8 \%$ polyacrylamide- $8 \mathrm{M}$ urea sequencing gel.

Construction of insulin receptor-CAT expression vectors. To test for functional activity, DNA fragments from the regulatory region of the insulin receptor gene were inserted into the unique Pst 1 and Sal 1 sites of the promoterless pCAT-Basic vector and cloned so that the recombinant vectors contained the $\mathrm{E} 3$ or $\mathrm{C} 2$ sequences either in the sense or antisense (as) orientation, both upstream from the bacterial chloramphenicol acetyltransferase (CAT) reporter gene. All plasmid constructs (pCAT-C2, pCAT-E3, pCAT-C2as, and pCAT-E3as) were verified by restriction enzyme mapping, transfected into $\mathrm{HB} 101$ bacterial cells, grown in large scale culture, and purified by cesium-chloride density gradient ultracentrifugation (35).

Transient expression studies. $16 \mathrm{~h}$ before transfection, HepG 2 cells were plated in $60-\mathrm{mm}$ dishes at a density of $5 \times 10^{5}$. Plasmid constructs and $\mathrm{pSV}-\beta$-galactosidase control plasmid were then transfected into HepG 2 cells by the calcium phosphate precipitation method (37). $48 \mathrm{~h}$ after transfection, cell extracts were prepared by three cycles of freezing-thawing, heated to $65^{\circ} \mathrm{C}$ for $10 \mathrm{~min}$ to inactivate endogenous deacetylases, then assayed for CAT activity with $0.25 \mathrm{mCi}$ $\left[{ }^{14} \mathrm{C}\right.$ ]chloramphenicol in a $125-\mu \mathrm{l}$ reaction (37). Quantitation of CAT activity was done by either laser densitometric scanning of the autoradiograms of TLC separation of CAT reaction products or by liquid scintillation counting (LSC) of the two major acetylated forms of ${ }^{14} \mathrm{C}$ labeled chloramphenicol. As internal control of transfection efficiency, $\beta$-galactosidase activity was measured (Promega technical bulletin).

Insulin receptor radioimmunoassay. The insulin receptor content of nonmyogenic cell lines was measured by a specific radioimmunoassay as previously described (38). Cultured cells were solubilized with $50 \mathrm{mM}$ Hepes buffer containing 1\% Triton X-100,1 mM PMSF and $0.5 \mathrm{mg} / \mathrm{ml}$ bacitracin for $1 \mathrm{~h}$ at $4^{\circ} \mathrm{C}$. Values were measured on a standard curve using a purified human placenta insulin receptor as a standard (38).

\section{Results}

Effects of differentiation on insulin receptor gene transcription. When $\mathrm{BC} 3 \mathrm{H}-1$ myoblasts differentiated into myocytes (after 
lowering the FBS concentration from 20 to $1 \%$ ), there was an increase in the transcription rate for the insulin receptor as measured by run-on assays (Fig. 1). After $7 \mathrm{~d}$ of differentiation, the insulin receptor gene transcription increased fivefold as measured by laser densitometric scanning of the autoradiograms (Table I). When cells were incubated in media with $1 \%$ FBS plus $30 \mathrm{ng} / \mathrm{ml}$ FGF, insulin receptor gene transcription was not inhibited but rather increased further (Fig. 1 and Table I). As a control, the transcription rate of the mouse GAPDH gene was measured. The transcription rate of the GAPDH gene did not increase under the conditions studied.

Specific interaction of nuclear proteins from $\mathrm{BC} 3 \mathrm{H}-1$ cells with the regulatory region of the insulin receptor gene. To identify possible binding sites for trans-acting factors within the insulin receptor upstream region, a number of probes were generated using a clone containing $1.8 \mathrm{~kb}$ of $5^{\prime}$ genomic sequence for the insulin receptor (34). First, we digested the 1.8 kb genomic sequence into five fragments (A-E) by using the enzymes Bgl2, Pst1, Xho1, Hind3, Sst1, and Nco1, and then end-labeled them with ${ }^{32}$ P (Fig. 2). Next, nuclear extracts from BC3H-1 cells were incubated with each radiolabeled fragment and tested for the presence of specific DNA-binding factors using a gel retardation assay (27). In initial experiments using undifferentiated and differentiated $\mathrm{BC} 3 \mathrm{H}-1$ cells, in vitro binding activity was demonstrated in only two of the five DNA fragments used, fragment $C(-576 /-874)$ and fragment $E$ (-1304/-1818)(Fig. 2), whereas no DNA binding complexes were observed with fragments A, B, and D (data not shown). Further studies using smaller subfragments of fragments $C$ and E localized the binding sites to two regions covering -674 to -874 and -1662 to -1818 bp upstream of the insulin receptor ATG codon, designed C2 and E3, respectively (Fig. 2).

Detection of proteins that bind to the 156-bp subfragment $E 3$ of the insulin receptor gene. $4 \mu \mathrm{g}$ of nuclear protein derived from $\mathrm{BC} 3 \mathrm{H}-1$ cells were incubated with ${ }^{32} \mathrm{P}$-labeled subfragment E3 $(-1662 /-1818)$ of the insulin receptor gene in the presence of $1 \mu \mathrm{g}$ of poly $(\mathrm{dl}-\mathrm{dC}$ ) (which was used as competitor DNA for nonspecific DNA-binding proteins in the nuclear extracts). In $\mathrm{BC} 3 \mathrm{H}-1$ myoblasts, a relatively small amount of DNA protein was noted (Fig. $3 a$ and Table I). After $7 \mathrm{~d}$ of differentiation, nuclear extracts from $\mathrm{BC} 3 \mathrm{H}-1$ myocytes demonstrated four- to fivefold enhanced DNA-binding activity as evidenced by the presence of a retarded DNA-protein complex (Fig. $3 a$ and Table I). Incubation of subfragment E3 probe with nuclear extracts from $\mathrm{BC} 3 \mathrm{H}-1$ cells treated with FGF was

IR

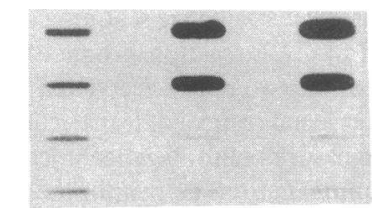

GAPDH

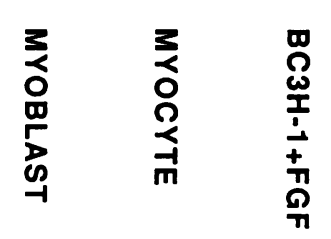

Figure 1. Insulin receptor gene transcription in BC3H-1 muscle cells. Nuclei were isolated from cells grown in media supplemented with either continuous $20 \%$ FBS (myoblast), $1 \%$ FBS for $7 \mathrm{~d}$ (myocyte), or $1 \%$ FBS for $7 \mathrm{~d}$ in the presence of $30 \mathrm{ng} /$ ml FGF (BC3H-1 + FGF), and nuclear run-on assays were then performed. As control, the transcription of the mouse GAPDH gene was also measured. IR, insulin receptor.
Table I. Comparison of Insulin Receptor Gene Transcription and DNA Binding Activity to Subfragments E3 and C2 in $\mathrm{BC} 3 \mathrm{H}-1$ Cells

\begin{tabular}{lccc}
\hline & & \multicolumn{2}{c}{ Gel retardation assay } \\
\cline { 3 - 4 } & Transcription assay & E3 & C2 \\
\hline Myoblasts & $1.0 \pm 0.06$ & $1.0 \pm 0.03$ & $1.0 \pm 0.10$ \\
Myocytes & $5.0 \pm 0.27$ & $4.5 \pm 0.50$ & $2.9 \pm 0.09$ \\
BC3H-1 + FGF & $9.3 \pm 0.50$ & $8.0 \pm 0.90$ & $4.8 \pm 0.10$
\end{tabular}

Cells were grown in 20\% FBS (myoblasts), and either transferred to $1 \%$ FBS for $7 \mathrm{~d}$ (myocytes) or transferred to $1 \%$ FBS plus $30 \mathrm{ng} / \mathrm{ml}$ FGF for $7 \mathrm{~d}$ (BC3H-1 + FGF). Values represent arbitrary units as measured by laser densitometry. Results are the mean \pm SEM for three separate experiments.

associated with a further increase in this function (Fig. $3 a$ and Table I). The increase in DNA binding by E3 paralleled the increase in insulin receptor gene transcription.

Detection of proteins that bind to the 200-bp subfragment $C 2$ of the insulin receptor gene. We next incubated nuclear extracts from BC3H-1 cells with ${ }^{32} \mathrm{P}$-labeled subfragment $\mathrm{C} 2$ $(-674 /-874)$. The results demonstrated that an insulin receptor DNA-binding complex was also detectable within this region of the insulin receptor gene. Like the E3 DNA-protein complex described above, it increased with differentiation of myoblasts into myocytes and was further increased by FGF treatment (Fig. $3 b$ and Table I). As with subfragment E3, the increase in nuclear binding by $\mathrm{C} 2$ paralleled the increase in insulin receptor gene transcription.

Specificity of DNA-protein binding. To determine specificity of DNA-protein binding, competition assays were performed. A 30-fold excess of either unlabeled subfragment E3 or unlabeled subfragment $\mathrm{C} 2$ significantly reduced the binding of labeled E3 and labeled C2 to the DNA binding proteins, respectively (Fig. 4). Moreover, 22-mer double stranded synthetic oligonucleotides representing the consensus binding sites for the nuclear proteins Sp1, Ap1, Ap2, Ap3, and NF1 /CTF did not compete for binding of nuclear proteins to subfragments E3 and C2 even at 200-fold excess of competitor DNA (data not shown).

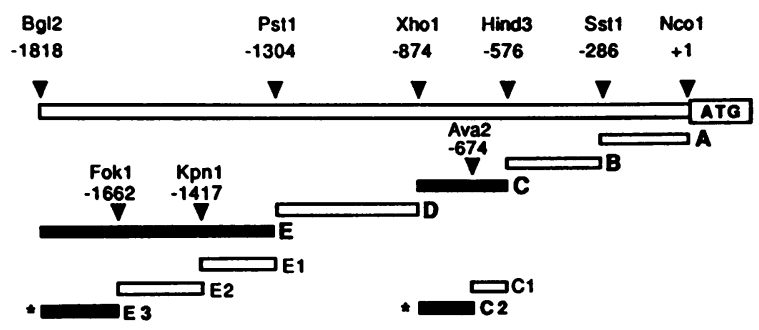

Figure 2. Restriction endonuclease map of the insulin receptor gene $5^{\prime}$ region showing fragments used in gel retardation assays. This portion of the gene shown extends from base +1 (in the ATG codon) of exon 1 to base -1818 . Regions of the gene that were used as probes in this study are indicated by A, B, C, D, E. Regions that demonstrated gel retardation are indicated by solid bars. Sites of endonuclease cleavage are shown. The smallest probes that interact with DNA binding proteins are preceded by an asterisk. 


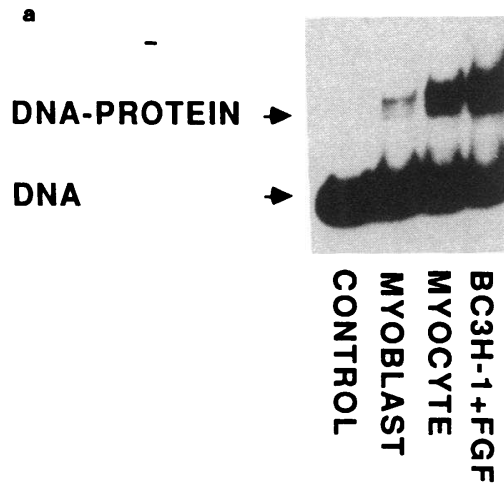

b

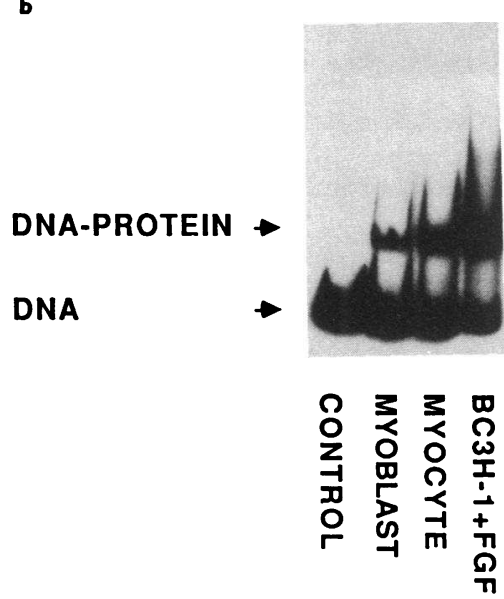

Figure 3. Gel retardation assays performed with the 156-bp subfragment E3 $(a)$ and 200-bp subfragment $C 2$ (b) in nuclear extracts of myoblasts, myocytes, and $\mathrm{BC} 3 \mathrm{H}-1$ cells grown in medium containing $1 \%$ FBS, in the presence of $30 \mathrm{ng} / \mathrm{ml}$ FGF (BC3H-1 + FGF). $4 \mu \mathrm{g}$ of extracts were incubated with E3 and $\mathrm{C} 2$ probes in the presence of $1 \mu \mathrm{g}$ poly (dl$\mathrm{dC}$ ), and DNA protein complexes were resolved on a nondenaturing $6 \%$ polyacrylamide gel. Arrows show the position of the DNA protein complexes.
Analysis of sequence-specific DNA binding proteins of the insulin receptor gene. DNase I protection experiments of myocyte nuclear extracts were performed to locate the binding site of the nuclear BC3H-1 proteins within the 156-bp E3 and 200bp C2 subfragments. We digested the radiolabeled fragments with DNase I in the presence of nuclear extracts and separated the free from the bound probe on a nondenaturing polyacrylamide gel. Using the same lane of the gel, the DNA was then extracted from the bands containing the bound and the free probes and analyzed on a sequencing gel. Significant protec-

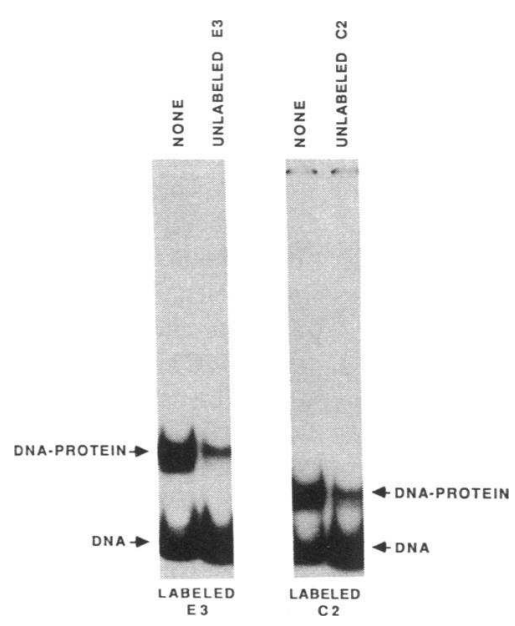

Figure 4. Competition for binding between nuclear proteins and insulin receptor gene subfragments. E3 subfragment (left) and $\mathrm{C} 2$ subfragment (right) were labeled and used as probes in gel retardation assays with $4 \mu \mathrm{g}$ of extracts from $\mathrm{BC} 3 \mathrm{H}-1$ myocytes under the same conditions as in Fig. 3. Sequence specificity of insulin receptor DNA binding proteins was determined by using a 30-fold molar excess of unlabeled subfragments $\mathrm{E} 3$ or $\mathrm{C} 2$ as competitors.

tion from DNase I digestion was observed over a poly A sequence of the coding strand of the E3 subfragment between positions $-1775 /-1784$ and $-1767 /-1740$ (Figs. 5 and 6 ). The presence, however, of a large poly A region refractory to DNase I cleavage did not allow us to unambiguously determine the precise 3 ' boundary of the protein binding site.

DNase I footprinting using the coding strand of the $\mathrm{C} 2$ bound and free probe was also carried out (Fig. 5). Protection from enzyme digestion was observed in the region of the protein binding site between nucleotides -782 and -800 (Figs. 5 and 6). Nuclear protein from myoblast extracts showed identical footprints over the two regions (data not shown).

Competition studies between E3 and C2 DNA subfragments of the insulin receptor gene. Since footprinting analysis of the E3 and C2 subfragments of the insulin receptor gene revealed protection of AT-rich regions, competition experiments using the synthetic polynucleotide poly(dA-dT) were carried out. The binding of myocyte nuclear proteins to subfragment E3 was almost abolished when increasing amounts of poly(dA$\mathrm{dT}$ ) were used in place of poly (dl-dC) (Fig. 7, $a$ and $b$ ). Similar results were obtained using the two polynucleotides with subfragment $\mathrm{C} 2$ (data not shown). Moreover, unlabeled subfragment E3 competitively inhibited the binding of labeled C2 to nuclear proteins (Fig. 8). In concert with this observation, unlabeled subfragment $\mathrm{C} 2$ inhibited the binding of labeled subfragment E3 to nuclear proteins (data not shown).

\section{SUBFRAGMENT SUBFRAGMENT E 3 C2}

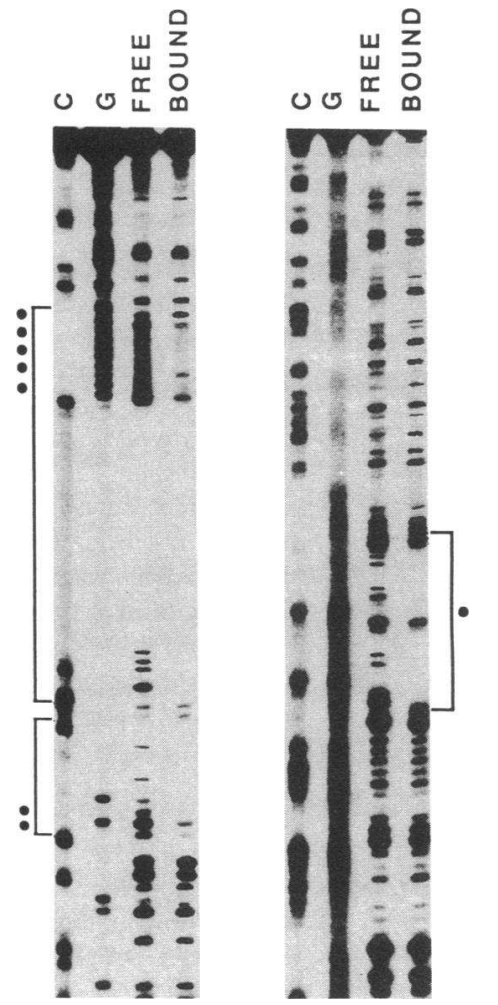

Figure 5. Analysis of DNA binding sites within the insulin receptor gene fragments as revealed by preparative gel retardation assays with DNase I footprinting. $\mathrm{BC} 3 \mathrm{H}-1$ myocyte nuclear extracts were incubated with either probe $\mathrm{E} 3$ or $\mathrm{C} 2$. After DNase I treatment, nondenaturing gels were carried out. DNA was extracted from the bands containing shifted and free probes, and again subjected to denaturing gels. As markers, the E3 subfragment and the $\mathrm{C} 2$ subfragment were cleaved by the Maxam and Gilbert (CG) method. The extent of protection from DNase I cleavage is shown by the brackets. Closed circles indicate partial protection. Note that the extent of the protected region in subfragment E3 cannot be determined precisely because it overlaps a poly $\mathrm{A}$ tract refractory to DNase I cleavage. 
SUBFRAGMENT E3

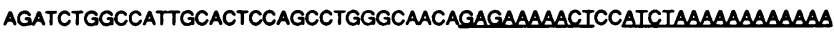
AAAAAAAAAAAAAAACAGAGAGAGAGAGAGAGAGAGAGAAGGAAACGGAACTGGGGGGAG GATTTGCAAAATATGGTTAGGGATGGCACTTCAG

SUBFRAGMENT C2

TCGAGTCACCAAAATAAACATTTTAATGCAGTATTITTTAAAAATTCAACAGGAATCCTCCA AAGCCCAGTATGAACAAAATAGCAAAATGGTAGAGAAAGGATCTGTGCCGCTGCGTCGGGC CTGTGGGGCGCCTCCGGGGGTCTGAAACTGGAGGAGACTCGGGGCTGTAGGGCGCGCGGAT CTGGGGCGCGCCCTCG

Figure 6. DNA sequences of subfragments E3 and C2, and a summary of footprinting protection results. The regions protected by nuclear proteins from DNase I cleavage are underlined.

Protein binding activity of subfragments E3 and C2 to nuclear extracts from other cell types. We next determined whether the DNA nuclear binding proteins detected toward the $\mathrm{E} 3$ and $\mathrm{C} 2$ subfragments of the regulatory region of the insulin receptor gene were specific to muscle cells. Therefore, we analyzed nuclear extracts from other cell lines: mouse 3T3-L1 cells (32), HepG2 human hepatoma cells (39), IM-9 human lymphocytes (38), and HTC rat hepatoma cells (40). Mouse 3T3L1 cells (and related cell lines) can be induced to differentiate from preadipocyte fibroblasts into adipocytes (41). Concomitant with differentiation, insulin receptor mRNA (25) and insulin receptor binding (42) markedly increase. Nuclear extracts from preadipocytes had relatively low binding to subfragments E3 and C2 (Fig. 9, $a$ and $b$ ). After differentiation into adipocytes, nuclear protein binding to DNA increased markedly (Fig. 9, $a$ and $b$ ).

HepG2 and IM-9 cells, which have relatively high concentrations of insulin receptors $(38,39)$, had relatively high concentrations of DNA binding proteins for both subfragments (Table II). In contrast, HTC cells, which have relatively low concentrations of insulin receptors $(40)$, had relatively low

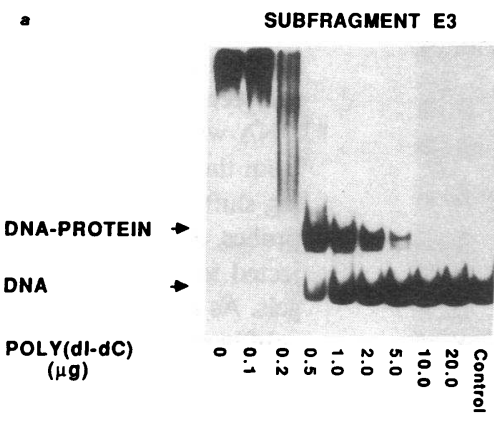

b SUBFRAGMENT E3

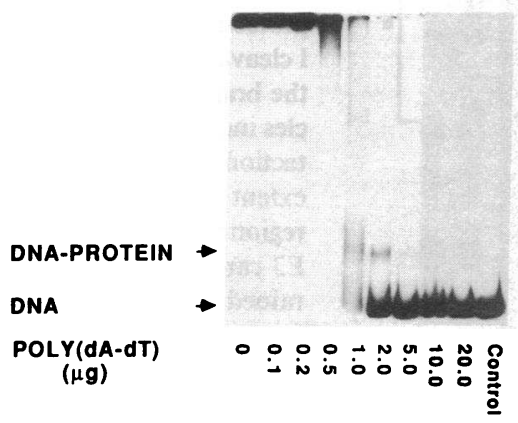

polynucleotides poly $(\mathrm{dl}-\mathrm{dC})$ and poly (dA-dT) on gel retardation assays with BC3H-1 myocyte extracts using the 156-bp subfragment E3 as probe. End-labeled E3 probe was incubated with $4 \mu \mathrm{g}$ of nuclear extracts from $\mathrm{BC} 3 \mathrm{H}-1$ myocytes in the presence of increasing amounts of poly (dl-dC) $(a)$ or poly (dA-dT) $(b)$ (0.1-20 $\mu \mathrm{g})$ and DNA protein complexes were resolved as in Fig. 3. Arrows show the position of the DNA protein
COMPETITOR:

SUBFRAGMENT E3 (molar excess)
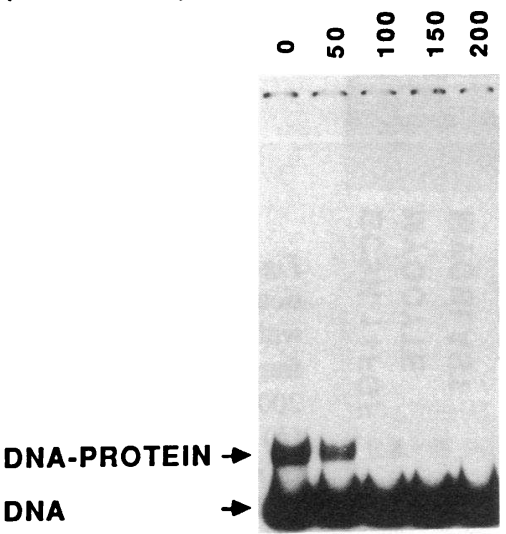

Figure 8. Cross-competition analysis of E3 and C2 DNA subfragments. End-labeled C2 probe was incubated with $4 \mu \mathrm{g}$ of nuclear extracts from BC3H-1 myocytes in the presence of increasing amounts of unlabeled E3 DNA subfragment.

concentrations of DNA binding proteins for both subfragments ( Table II).

Functional analysis of subfragments $E 3$ and $C 2$ of the insulin receptor gene. To investigate whether these two proteinDNA binding sites of the insulin receptor gene were important for transcriptional activation, both subfragments E3 and C2 were ligated into the polylinker site of the promoterless pCATBasic vector, upstream of the CAT reporter gene, either in the sense or antisense (as) orientation. These new vectors (pCATC2, pCAT-C2as, pCAT-E3, and pCAT-E3as) were transiently transfected into HepG 2 cells, a cell line that readily expresses

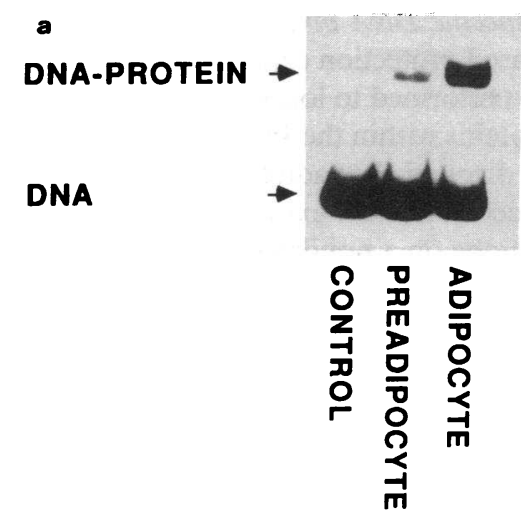
complexes.

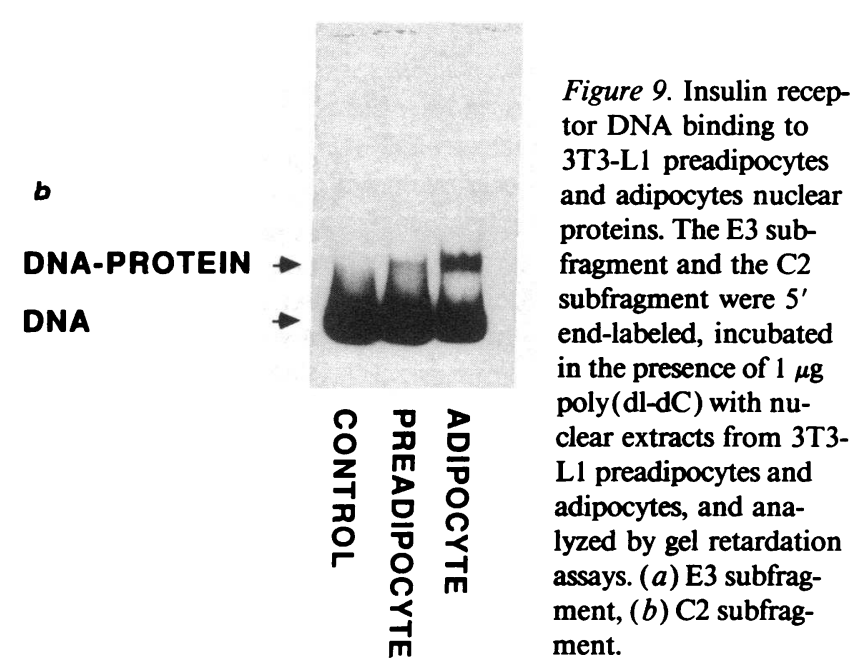


Table II. Comparison of Insulin Receptor Concentration and DNA Binding Activity to Subfragments $E 3$ and $C 2$ in Other Cell Types

\begin{tabular}{lccr}
\hline & & \multicolumn{2}{c}{ Gel retardation assay } \\
\cline { 3 - 4 } & & \multicolumn{1}{c}{ E3 } & \multicolumn{1}{c}{ C2 } \\
\hline & Insulin receptor content & & \\
HTC & $n g / m g$ protein & & \\
IM-9 & $9.7 \pm 4.2$ & $1.0 \pm 0.1$ & $1.0 \pm 0.1$ \\
HepG2 & $102.0 \pm 10.5$ & $10.9 \pm 1.0$ & $8.0 \pm 2.2$ \\
& $130.0 \pm 7.5$ & $15.0 \pm 1.5$ & $12.2 \pm 1.1$ \\
\hline
\end{tabular}

* Radioimmunoassay. ${ }^{\ddagger}$ Values represent arbitrary units as measured by laser densitometry. Results are the mean \pm SEM for three separate experiments.

both insulin receptor DNA-binding proteins (Table II). Cell extracts were prepared and CAT activity was assayed by either the TLC separation of CAT reaction products or by using the more sensitive LSC method. The results of these studies demonstrated that $\mathrm{C} 2$ - and E3-containing vectors exhibited a fourand eightfold increase in CAT expression, respectively (Fig. 10). In contrast, no CAT activity was observed in E3as- and C2as-containing vectors when compared with the parent promoterless pCAT-Basic vector (Fig. 10). Interestingly, in transfected HTC cells, in which the abundance of both insulin receptor-DNA binding proteins is relatively low, CAT activity of E3- and C2-containing vectors was significantly reduced, compared with that of HepG2 cells (data not shown). In initial experiments, each subfragment was inserted downstream of the CAT gene, into a plasmid containing SV40 promoter se-

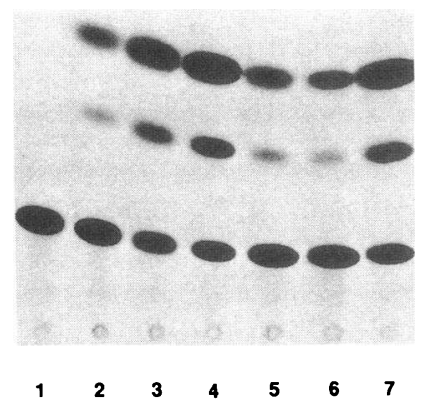

Figure 10. CAT activity directed by subfragments E3 and C2. Recombinant plasmids containing 5 ' flanking DNA sequences of the insulin receptor were transfected into HepG2 cells. $48 \mathrm{~h}$ after transfection, cell extracts were prepared and CAT activity was measured.

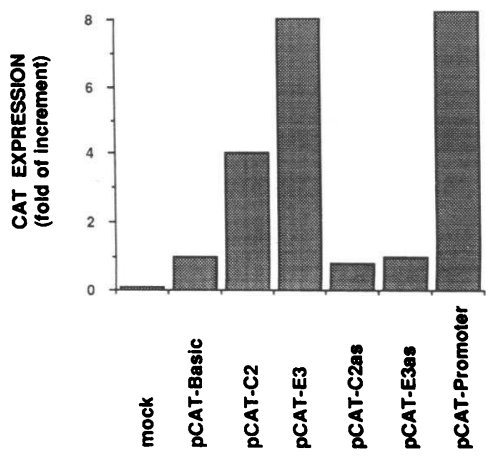
(Top) Autoradiogram illustrating CAT activity associated with each constructs after TLC separation. Lanes: 1 , no DNA; 2, pCAT-Basic vector without an insert; 3, pCAT-C2; 4, pCATE3; 5, pCAT-C2as; 6 , pCAT-E3as; 7, pCATPromoter vector, a positive control having the simian virus 40 gene promoter upstream of the CAT. (Bottom)

CAT activity was assayed by LSC of the two major acetylated forms of ${ }^{14} \mathrm{C}$-labeled chloramphenicol in the upper xylene phase. A representative of three separate transfections is shown.

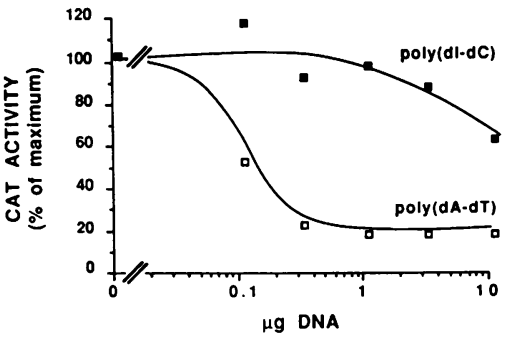

Figure 11. Dose-dependent inhibition of E3driven CAT activity by the synthetic poly (dAdT). $10 \mu \mathrm{g}$ of pCAT-E3 vector were transfected into HepG2 cells in the presence of increasing concentrations $(0.1-10$ $\mu \mathrm{g})$ of either poly (dA-

$\mathrm{dT}$ ) or poly ( $\mathrm{dl}-\mathrm{dC}) .48 \mathrm{~h}$ after transfection, cell extracts were prepared and CAT activity was quantified by LSC, as in Fig. 10. 100\% is the value in the absence of synthetic DNA. A representative of three separate transfections is shown. Each point represents the mean of triplicate values.

quences upstream of the CAT coding region ( $\mathrm{pCAT}$-Promoter vector). Neither E3 nor C2 exhibited CAT activity (data not shown).

Therefore, these results strongly indicate that these two sequences of the regulatory region of the insulin receptor gene have functional activity and act as promoter elements driving transcription of the CAT reporter gene when transfected into mammalian cells.

Inhibition of CAT activity by the synthetic polynucleotide poly $(d A-d T)$. Because of its ability to compete for binding of myocyte nuclear proteins to E3 and C2 subfragments in vitro, we next examined whether the synthetic polynucleotide poly (dA-dT) could interfere with the transcriptional activity of insulin receptor sequence-specific DNA binding proteins in vivo. Competition experiments were carried out by transfecting the polynucleotide poly (dA-dT) into HepG2 cells in the presence of either pCAT-C2 or pCAT-E3 vectors. A similar approach has been successfully used to inhibit the expression of endogenous interleukin 2 gene in mammalian cells (43). Fig. 11 shows a dose-dependent inhibition of E3-driven CAT activity by the synthetic polynucleotide. Poly(dA-dT) at $200 \mathrm{pM}$ caused $>80 \%$ decrease in this function. Higher concentrations of poly(dA-dT) had no further effects. In contrast, when poly ( $\mathrm{dl}-\mathrm{dC}$ ) was used in place of poly (dA-dT), a small nonspecific reduction in E3-dependent CAT activity was observed (Fig. 11). Similar results were obtained using both polynucleotides with the pCAT-C2 vector (data not shown).

\section{Discussion}

The insulin receptor is present in many cells, but its expression is variable due to tissue-specific factors, hormones, and differentiation $(2-5,16,17)$. In this study, we employed $\mathrm{BC} 3 \mathrm{H}-1$ muscle cells in which differentiation induces a marked increase in insulin receptor gene transcription $(13,20)$. We used gel retardation assays to detect two discrete regions of the insulin receptor gene that specifically interact with nuclear binding proteins. Binding of nuclear extracts to both regions markedly increased with differentiation. This increase paralleled the increase in insulin receptor gene transcription. Moreover, FGF increased the amount of these proteins. Since FGF blocks the differentiation-induced increase of muscle-specific proteins $(13,20)$, these data indicated, therefore, that these nuclear binding proteins for the insulin receptor gene are regulated by a different mechanism than that which regulates muscle specific proteins. 
We also studied several non-muscle cell lines. In 3T3-L1 cells, differentiation from preadipocytes to adipocytes was associated with the appearance of the two nuclear binding proteins. In HepG2 hepatocytes and IM-9 lymphocytes, two cell lines with relatively high insulin receptor expression, the same two insulin receptor DNA binding proteins were readily detected. In contrast, in HTC rat hepatoma cells, a cell line with relatively low insulin receptor expression, these two proteins were not readily detected. These data indicate, therefore, that these nuclear binding proteins for the insulin receptor gene are not specific to muscle cells, and in other tissues they appear to correlate with insulin receptor content.

DNase I protection analysis revealed that the myocyte nuclear factors obtained from BC3H-1 cells protected two ATrich sequences of subfragments E3 and C2. In both subfragments, increasing amounts of poly (dA-dT) resulted in a concomitant decrease in in vitro nuclear protein binding to DNA, suggesting that these two sequences of the insulin receptor gene may bind to the same nuclear protein. Unlabeled subfragments E3 and C2 also cross-competed for nuclear binding. These two sequences, therefore, may represent binding sites for the same nuclear protein, or, alternatively, they may represent binding sites for two members of a family of transcription factors that have evolved to recognize distinct but related sequences.

Functional analysis with the CAT reporter gene demonstrated that both E3 and $\mathrm{C} 2$ sequences of the regulatory region of the insulin receptor gene had a significant ability to drive transcription in intact cells. The fact that this activity was totally dependent upon the orientation of E3 and C2 strongly suggests that these sequences act as promoter elements. The ability of E3 and C2 to drive transcription in intact cells was almost completely abolished by preventing the binding of nuclear proteins to DNA using the synthetic polynucleotide poly (dA-dT).

DNA binding protein interactions with poly $(\mathrm{dA}-\mathrm{dT})$ tracts of promoters has not been previously reported in mammalian genes. However, -oligo(dA)-oligo(dT) tracts have been described in yeast DNA and act as promoter elements (44-46). For at least three different yeast genes, naturally occurring stretches of poly (dA-dT) are located upstream of coding sequences $(44,45)$. Deletion of these sequences markedly diminishes transcription, whereas increasing the length of these sequences enhances their activity $(44,45)$. Moreover, it has been shown that properly phased A-tract sequences increase the rate of transcription initiation at the Escherichia coli lac promoter (47). It has been proposed that these transcriptional effects may be due to exclusion of nucleosomes from poly (dA-dT) regions. The present finding, that the insulin receptor has poly $(\mathrm{dA}-\mathrm{dT})$ tracts that interact with DNA-binding proteins, is the first report therefore of regulatory functions for this type of DNA in higher eucaryotes. It should be pointed out that nuclear binding to poly (dA-dT) tracts is relatively specific since fragment $\mathrm{D}$ also has such a tract, but DNA binding activity within this fragment could not be detected.

The insulin receptor is a member of a supergene family that includes the closely related IGF-I receptor and the more distantly related EGF receptor (48). The IGF-I receptor promoter region has several poly (dA-dT) stretches, but their role in transcriptional control remains to be defined. The EGF receptor does not have similar poly (dA-dT) stretches. For the EGF receptor, transcription appears to be regulated by $\mathrm{Sp} 1$ and receptor specific factors $(49,50)$.
In light of these results, our studies of two subfragments of the insulin receptor gene that show DNA binding ( $-674 /-874$ and $-1662 /-1818$ upstream of the insulin receptor ATG codon) are in general agreement with in vitro functional studies, whereby the influence of promoter subfragments was studied on the activity of a reporter gene such as CAT. Although promoter activity was contained in the first $579 \mathrm{bp}$ of the insulin receptor $5^{\prime}$ flanking region (21-25), other reports suggested that the full-length promoter region is needed for maximal activity (24).

In summary, we have identified two DNA binding proteins that are associated with cells that express insulin receptors. These binding proteins interact with unique poly(dA-dT) stretches that are functionally active. These observations raise the possibility therefore that insulin receptor expression in target tissues is regulated at least in part by these nuclear binding proteins.

\section{Acknowledgments}

This work was supported by grants from the Juvenile Diabetes Foundation International and the National Institutes of Health (AM26667).

We thank Dr. M. Alexander for her gift of 3T3-L1 nuclear extracts and Dr. P. Goodman for providing the insulin receptor promoter DNA. Special thanks to Dr. R. Vigneri for critical discussions of this manuscript.

\section{References}

1. Goldfine, I. D. 1981. Effects of insulin on intracellular functions. In Biochemical Actions of Hormones, Volume 8. G. Litwack, editor. Academic Press, Inc. New York. 272-305.

2. Goldfine, I. D. 1987. The insulin receptor: molecular biology and transmembrane signalling. Endocr. Rev. 8:235-255.

3. Kahn, C. R. 1985. The molecular mechanisms of insulin action. Annu. Rev. Med. 36:429-451.

4. Czech, M. P. 1985. The nature and regulation of insulin receptor: structure and function. Annu. Rev. Physiol. 47:357-381.

5. Jacobs, S., and P. Cuatrecasas. 1981. Insulin receptor: structure and function. Endocr. Rev. 2:251-263.

6. Standaert, M. L., S. D. Schimmel, and R. J. Pollet. 1984. The development of insulin receptors and responses in the differentiating non-fusing muscle cell line BC3H-1. J. Biol. Chem. 259:2337-2345.

7. Beguinot, F., C. R. Kahn, A. C. Moses, and R. J. Smith. 1986. The development of insulin receptors and responsiveness is an early marker of differentiation in the muscle cell line L6. Endocrinology. 118:446-455.

8. Olson, E. N., K. L. Caldwell, J. P. Gordon, and L. Glaser. 1983. Regulation of creatine phosphokinase expression during differentiation of $\mathrm{BC} 3 \mathrm{H}-1$ cells. $J$. Biol. Chem. 258:2644-2652.

9. Munson, R., Jr., K. L. Caldwell, and L. Glaser. 1982. Multiple controls for the synthesis of muscle-specific proteins in $\mathrm{BC}_{3} \mathrm{H} 1$ cells. J. Cell Biol. 92:350-356.

10. Strauch, A. R., and P. A. Rubenstein. 1984. Induction of vascular smooth muscle $\alpha$-isoactin expression in BC3H-1 cells. J. Biol. Chem. 259:3152-3159.

11. Olson, E. N., L. Glaser, J. P. Merlie, and J. Lindstrom. 1984. Expression of acetylcholine receptor $\alpha$-subunit mRNA during differentiation of $\mathrm{BC} 3 \mathrm{H}-1$ muscle cell line. J. Biol. Chem. 259:3330-3336.

12. Brunetti, A., B. A. Maddux, K. Y. Wong, and I. D. Goldfine. 1989. Muscle cell differentiation is associated with increased insulin receptor biosynthesis and messenger RNA levels. J. Clin. Invest. 83:192-198.

13. Brunetti, A., and I. D. Goldfine. 1990. Differential effects of fibroblast growth factor on insulin receptor and muscle specific protein gene expression in BC3H-1 myocytes. Mol. Endocrinol. 4:880-885.

14. Farese, R. V., D. E. Barnes, J. S. Davis, M. L. Standaert, and R. J. Pollet. 1984. Effects of insulin and protein synthesis inhibitors on phospholipid metabolism, diacylglycerol levels, and pyruvate dehydrogenase activity in $\mathrm{BC} 3 \mathrm{H}-1$ cultured myocytes. J. Biol. Chem. 259:7094-7100.

15. Cooper, D. R., T. S. Konda, M. L. Standaert, J. S. Davis, R. J. Pollet, and R. V. Farese. 1987. Insulin increases membrane cytosolic protein kinase activity in BC3H-1 myocytes. J. Biol. Chem. 262:3633-3639.

16. Olefsky, J. M. 1980. Insulin resistance and insulin action. An in vitro and in vivo perspective. Diabetes. 30:148-162.

17. Mamula, P. W., A. R. McDonald, A. Brunetti, Y. Okabayashi, K. Y. 
Wong, B. A. Maddux, C. Logsdon, and I. D. Goldfine. 1990. Regulating insulinreceptor gene expression by differentiation and hormones. Diabetes Care. 13:288-301.

18. Davis, R. L., H. Weintraub, and A. B. Lassar. 1987. Expression of a single transfected cDNA converts fibroblasts to myoblasts. Cell. 51:987-1000.

19. Wright, W. E., D. A. Sassoon, and V. K. Lin. 1989. Myogenin, a factor regulating myogenesis, has a domain homologous to MyoD. Cell. 56:607-617.

20. Brunetti, A., and I. D. Goldfine. 1990. Role of myogenin in myoblast differentiation and its regulation by fibroblast growth factor. J. Biol. Chem. 265:5960-5963.

21. Araki, E., F. Shimada, H. Uzawa, M. Mori, and Y. Ebina. 1987. Characterization of the promoter region of the human insulin receptor gene. J. Biol. Chem. 262:16186-16191.

22. Mamula, P. W., K. Y. Wong, B. A. Maddux, A. R. McDonald, and I. D. Goldfine. 1989. Sequence and analysis of the promoter region of the human insulin receptor gene. Diabetes. 37:1241-1246.

23. Seino, S., M. Seino, S. Nishi, and G. I. Bell. 1989. Structure of the human insulin receptor gene and characterization of its promoter. Proc. Natl. Acad. Sci. USA. 86:114-118.

24. Tewari, D. S., D. M. Cook, and R. Taub. 1989. Characterization of the promoter region and $3^{\prime}$ end of the human insulin receptor gene. J. Biol. Chem. 264:16238-16245.

25. Sibley, E., T. Kastelic, T. J. Kelly, and M. D. Lane. 1989. Characterization of the mouse insulin receptor gene promoter. Proc. Natl. Acad. Sci. USA. 86:9732-9736.

26. Dynan, W. S., and R. Tjian. 1985. Control of eukaryotic messenger RNA synthesis by sequence specific DNA binding proteins. Nature (Lond.). 316:774778.

27. Rhodes, D. 1990. Analysis of sequence-specific DNA binding proteins. In Protein Function, A Practical Approach. T. Creighton, editor. IRL Press, Oxford. 177-223.

28. Shaw, D. J., and G. I. Bell. 1985. Rsal polymorphism at the insulin receptor locus (INSR) on chromosome 19. Nucleic Acids Res. 13:8659-8661.

29. Wadsworth, H. L., D. G. Chazenbalk, and B. Rapoport. 1990. Thyrotropin can increase the steady state level of a messenger ribonucleic acid species (glyceraldehyde-3-phosphate dehydrogenase) in thyroid cells by decreasing its rate of disappearance. Endocrinology. 127:5-9.

30. Dignam, J. D., R. M. Lebovitz, and R. G. Roeder. 1983. Accurate transcription by RNA polymerase II in a soluble extract from isolated mammalian nuclei. Nucleic Acids Res. 11:1475-1489.

31. Bradford, M. M. 1976. A rapid and sensitive method for the quantitation of microgram quantities of protein utilizing the principle of protein-dye binding. Anal. Biochem. 72:248-254.

32. Nasrin, N., L. Ercolani, M. Denaro, X. F. Kong, I. Kang, and M. Alexander. 1990. An insulin response element in the glyceraldehyde-3-phosphate dehydrogenase gene binds a nuclear protein induced by insulin in cultured cells and by nutritional manipulations in vivo. Proc. Natl. Acad. Sci. USA. 87:5273-5277.

33. Gossett, L. A., D. J. Kelvin, B. A. Sternberg, and E. N. Olson. 1989. A new myocyte-specific enhancer-binding factor that recognizes a conserved element associated with multiple muscle-specific genes. Mol. Cell. Biol. 11:5022-5033.

34. Goodman, P. A., P. Sbraccia, A. Brunetti, K. Y. Wong, J. D. Carter, S. M.
Rosenthal, and I. D. Goldfine. 1992. Growth factor receptor regulation in the minn-1 leprechaun: defects in both insulin receptor and EGF receptor gene expression. Metab. Clin. Exp. 41:504-509.

35. Sambrook, J., E. F. Fritsch, and T. Maniatis. 1989. Molecular Cloning: A Laboratory Manual. Cold Spring Harbor Laboratory, Cold Spring Harbor, NY.

36. Maxam, A. M., and W. Gilbert. 1980. Sequencing end-labeled DNA with base-specific chemical cleavages. Methods Enzymol. 65:499-560.

37. Gorman, C., L. Moffat, and B. Howard. 1982. Recombinant genomes which express chloramphenicol acetyltransferase in mammalian cells. Mol. Cell. Biol. 2:1044-1051.

38. Pezzino, V., V. Papa, V. Trischitta, A. Brunetti, P. A. Goodman, M. K. Treutelaar, J. A. Williams, B. A. Maddux, R. Vigneri, and I. D. Goldfine. 1989. Human insulin receptor radioimmunoassay: applicability to insulin-resistant states. Am. J. Physiol. 257:E451-E457.

39. Podskalny, J. M., S. Takeda, R. E. Silverman, D. Tran, J. L. Carpentier, L. Orci, and P. Gorden. 1985. Insulin receptors and bioresponses in a human liver cell line (HepG2). Eur. J. Biochem. 150:401-407.

40. Hawley, D. M., B. A. Maddux, R. G. Patel, K. Y. Wong, P. W. Mamula, G. L. Firestone, A. Brunetti, E. Verspohl, and I. D. Goldfine. 1989. Insulin receptor monoclonal antibodies that mimic insulin action without activating tyrosine kinase. J. Biol. Chem. 264:2438-2444.

41. Green, H., and O. Kehinde. 1975. An established pre-adipose cells line and its differentiation in culture. Cell. 5:19-27.

42. Karlsson, F. A., C. Grunfeld, C. R. Kahn, and J. Roth. 1979. Regulation of insulin receptors and insulin responsiveness in 3T3-L1 fatty fibroblasts. Endocrinology. 104:1383-1392.

43. Bielinska, A., R. A. Shivdasani, L. Zhang, and G. J. Nabel. 1990. Regulation of gene expression with double-stranded phosphorothioate oligonucleotides. Science (Wash. DC). 250:997-1000.

44. Russel, D. W., M. Smith, D. Cox, V. M. Williamson, and E. F. Young. 1983. DNA sequences of two yeast promoter-up mutants. Nature (Lond.) 304:652-654

45. Struhl, K. 1985. Naturally occurring poly(dA-dT) sequences are up stream promoter elements for constitutive transcription in yeast. Proc. Natl. Acad. Sci. USA. 82:8419-8423.

46. Nelson, H. C. M., J. T. Finch, B. F. Luisi, and A. Klug. 1987. The structure of an oligo(dA) oligo(dT) tract and its biological implications. Nature (Lond.) $330: 221-226$

47. Gartenberg, M. R., and D. M. Crothers. 1991. Synthetic DNA bending sequences increase the rate of in vitro transcription initiation at the Escherichia coli lac promoter. J. Mol. Biol. 219:217-230.

48. Ishii, S., Y.-H. Xu, R. H. Stratton, B. A. Roe, G. T. Merlino, and I. Pastan 1985. Characterization and sequence of the promoter region of the human epidermal growth factor receptor gene. Proc. Natl. Acad. Sci. USA. 82:4920-4924.

49. Kageyama, R., G. T. Merlino, and I. Pastan. 1988. Epidermal growth factor (EGF) receptor gene transcription. Requirement for Spl and an EGF receptor-specific factor. J. Biol. Chem. 263:6329-6336.

50. Maekawa, T., F. Imamoto, G. T. Merlino, I. Pastan, and S. Ishii. 1989. Cooperative function of two separate enhancers of the human epidermal growth factor receptor proto-oncogene. J. Biol. Chem. 264:5488-5494. 